NASA Technical Memorandum 82740

\title{
Progress in Protective Coatings for Aircraft Gas Turbines: A Review of NASA Sponsored Research
}

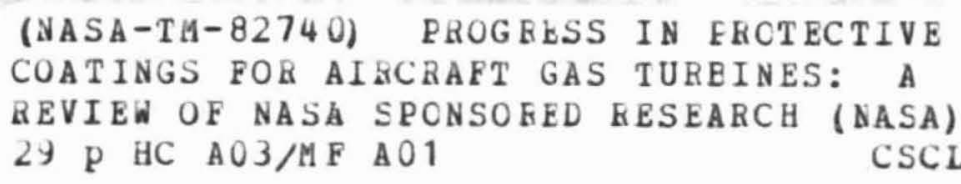

John P. Merutka

Lewis Research Center

Cleveland, Ohio

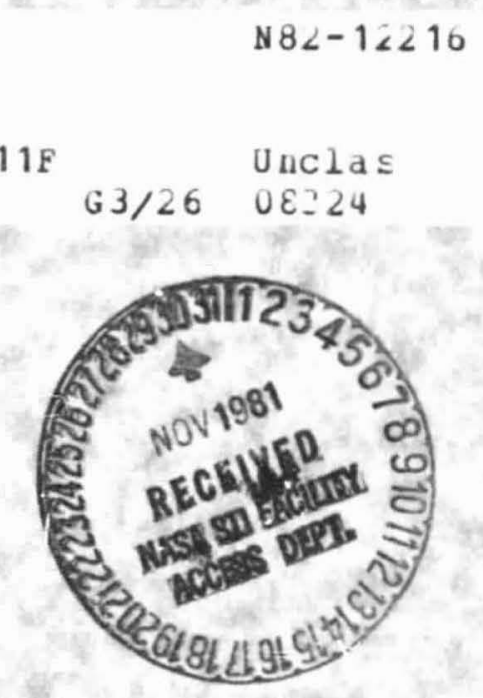

Prepared for the

Fifth Annual Conference on Composites and Advanced Materials sponsored by the American Ceramic Society, Inc.

Merritt Island, Florida, January 19-22, 1981 


\title{
Progress in Protective Coatings for Aircraft Gas Turbines:
}

A Review of MASA Sponsored Research

\author{
John P. Merutka \\ MASA Lewis Research Center \\ Cleveland, Onto 44135
}

\section{ABSTRACT}

The status of several recent NASA sponsored coatings technology programs are reviewed. These efforts were focused on problems associated with advanced aircraft gas turbines. In one program, metallic coatings for preventing titanium fires in compressurs were identified. The other four efforts were focused on coatings for the turbine section. In one of the latter, ductile aluminide coatings for protecting internal turbine-blade cooling passage surfaces were identified. In a second, composition-modified external overlay MCrAir coatings deposited by low-pressure plasma sprayings were found to be better in surface protection capability than vapor deposited MCrAlY coatings. The remaining two efforts focused on thermal barrier coatings (TBC). In one, computer-aided manufacturing technology was applied to the TBC coating of turbine airfoils. In the other, the design of a turbine airfoil was integrated with a TBC.

\section{INTRODUCTION}

In the past ten years, the MASA Lewis coatings programs stressed the improvement of aluminide and metal overlay coatings for aircraft gas turbines (References 1-14) and coated metallic and ceramic heat shield concspts 
(References 15-24) for the space shuttle. Recently, our efforts have focused exclusively on advanced coating systems for aircraft gas turbines. The need for improved oxidatior. :esistant coatings arises from the development of alloys with increased operating temperature/strength capability. but with poor environmental resistance. Very often these advanced alloys have mechanical or chemical properties which limit the use of conventional coatings; therefore, the alloy, the coating, and the turbine blade design are being addressed as an integral system.

With ever-increasing turbine temperature and pressures, protective coatings are not only required for external gas turbine airfoll surfaces but also for internal air-cooling passages. One recent NASA-sponsored program has addressed this internal coating need. In the jast internal passage protection was obtained by a vapor deposited coating from a pack process. Coating composition was limited to that of a simple aluminide with accompanying low ductility.

The physical vapor deposited MCrAly coatings were devioped in the 1970's. Today, MCrAlY coatings needed to meet the protection requirements of aavanced engine alloys are limited by compositional flexibility problems. In addition, high capital-cost equipment is required. These factors and the recent development of thermal barrier coatings (TBC) have resulted in our focusing the bulk of our effort on plasma sprayed coatings. Advances in plasma spray equipment and in computer-aided manufacturing are being exploited. The low-pressure plasma spray process has been used in one contract to expand the range of available metallic coating compositions and properties. In another contract effort, adaptive computerized plasma-spray 
coating equipment has been developed for the application of thermal barrier coatings. Adhering to the systems approach for advanced coatings, thermal barrier coating thickness contour can be designed and successfully manufactured with this equipment. This substrate/coating system philosophy was applied in another contract aimed at tailoring of a thermal barrier coating/gas turbine blade design.

In a departure from our past in-house and contractual dealing with the area of high-temperature surface protection efforts, a contract addressed the problem of titanium combustion in aircraft engine compressors. This effort was directed at prevention of sustained titanium combustion by means of protective coatings.

What follows are summaries of the results of five recently-completed contracts and a look at our future thrusts. The titanium combustion problem and the process development for internal coatings will be covered first followed by the MCrAlY and TBC coating stidisss and the automated plasma spray equipment development.

COATINGS FOR TITANIUM COMPRESSOR BLAOES

Based on strength-to-density ratio up to $480^{\circ} \mathrm{C}\left(900^{\circ} \mathrm{F}\right)$, titanium offers a substantial weight reduction in gas turbine engine compressor components. However, there is one significant probiem with titanium-combustion. When sufficient energy is supplied to titanium, it will spontaneously ignite (exothermic reaction) and continue to burn and meit unt il consumed or the metal temperature is reduced below the ignition temperature. 
This problem has resulted in the removal of titanium alloys from selected regions in axial flow cumpressors-particularly to avoid potential of titanium-to-titanium rubs.

Two approaches to solve the problem of titanium fires in gas turbine compressors are abrasive blade tip treatments and coatings. The tip treacment approach is aimed at reducing the amount of energy transmitted to titanium blades during rubs with the case. With protective coatings, the surface melting and burn characteristics aite modified so that ignition events do not result in sustained combustion. The abrasive blade tip treatment approach was sponsored by the Air Force, and the coating approach by MASA. In both cases the contractor was the Government Products Division of Pratt and Whitney Aircraft (PWA, Florida).

The objective of the titanium coating program was to develop, starting with the thirteen coatings shown in Table I, a coating system which could protect titanium under energy input conditions that ignite bare titanium. In addition, the coating must have no adverse effect on the titanium physical and mechanical priperties, especially hign cycle fatigue life. Using a laboratory laser screening test under the conditiens shown in Table 1 , seven coatings provided ignition resistance at normal engine operating conditions and also under a more severe condition of increased temperature. However, ignition occurred in all seven of these coatings under temperature and pressure conditions beyond engine operating conditions. Examples of the burn response of the most fire-resistant coating, $\mathrm{Pt} / \mathrm{Cu} / \mathrm{Ni}$, to a range of temperature/ pressure/velocity parameters, are shown in figure 1.

Normally, coatings applied to titanium cause a loss in fatigue life. To further evaluate the seven best coatings, reverse bending fatigue tests were 
carried out. The results are shown in figure 2. The ion vapor deposited (IVD) aluminum and $\mathrm{Pt} / \mathrm{Cu} / \mathrm{Mi}$ coatings gave high-cycle fatigue lives equivalent to bare Ti-8AI-1M0-1V.

Concurrent with this program, an Air Force Wright Aeronautical Laboratory/ Aeronautical Propulsion Laboratory (AFWAL/APL) contract with PWA, Florida examined the cascade combustion (molten metal ignition) of the IVD aluminum and electroplated Pt/Cu/Ni coatings developed under the MASA contract with PWA, Florida. The NASA sponsored effort examined the mechanical and physical properties of the two coatings on Ti-8AI-1Mo-1V and the AF alloy $(T i-3 A T-6 C r-8 V-4 M 0-4 Z r)$.

In a cascade combustion test, a um titanium specimen is placed upstream of a coated specimen. The bare spacimen is laser ignited, and the molten titanium flows over the coated specimen causing it to ignite. The cordwise burn velocity (combustion rate) and burn severity were determined over the following parameter ranges:

$\begin{array}{ll}\text { Pressure } & 0.275-0.520 \mathrm{MPa}(40-80 \mathrm{psia}) \\ \text { Temperature (gas) } & 315-440^{\circ} \mathrm{C}\left(660-875^{\circ} \mathrm{F}\right) \\ \text { Air Velocity } & 183-305 \mathrm{~m} / \mathrm{sec} .(600-1000 \mathrm{ft} / \mathrm{sec} .) \\ \text { Coatings } & \text { IVO aluminum Pt/Cu/Ni } .\end{array}$

Coating Thickness $0.005,0.008,0.010 \mathrm{~cm} .(0.002,0.003$, and 0.004 in.) Analysis of the data showed that the type of coating has no significant effect on cordwise burn velocity while increased coating thickness decreases it. Both pressure and air velocity have the greatest effect on cordwise burn velocity. Cordwise burn velocity increases with increasing pressure and temperature.

* All compositions in weight percent. 
In Table II is a summary of the tests used to determine what effect, if any, the $\mathrm{Pt} / \mathrm{Cu} / \mathrm{Ni}$ and IVD aluminum coatings had on several properties of Ti-8A1-1Mo-1V.

The conclusions from the program are that the $\mathrm{Pt} / \mathrm{Cu} / \mathrm{Ni}$ and IVD aluminum coatings provide potential systems to resist titanium ignition under certain high impact energy conditions.

As with all laboratory coating development programs, including three of the other programs described here, acceptance of a coating innovation or improvement requires engine verification. However, in this case, the risk in a ground-based engine test is high since titanium fires can destroy the engine. Therefore, engine verification of the potential of the abrasive blade tip treatments and the coatings to el iminate the titanium combustion problem can not be as readily confirmed as are other coating innovations. The report from this contract should be published during the second quarter of 1981, as NASA CR-165360.

\section{INTERNAL COATING OF AIR-COOLED GAS TURBINE BLADES}

Aircraft gas turbine engine performance has been improved by operating at higher temperatures and pressures. Air-cooling of first- and second-stage turbine blades and vanes were required to achieve the improved efficiency while keeping metal temperatures down to acceptabie levels. With thes'. higher operating temperatures and less resistant alloys, the external as well as the internal surfaces of blades and vanes need to be protected. Without internal coatings, internal passages with as much as ten percent of the cross-section consumed by hot corrosion have been seen in the field (Reference 25). The use 
of air-cooling in advanced airfoils also requires that both internal and external coatings be relatively ductile at low operating temperatures.

The objective of the inteinal coatings program with Solar was to develop coating compositions having balance of environmental resistance and low temperature ductility. Coatings were applied to IN-792 + Hf using the dry powder park method. The coating systems investigated were: $\mathrm{Ni}-19 \mathrm{Al}-1 \mathrm{Cb}$, $\mathrm{Ni}-19 \mathrm{Al}-3 \mathrm{Cb}, \mathrm{Ni}-12 \mathrm{Al}-20 \mathrm{Cr}$ and $\mathrm{Ni}-17 \mathrm{Al}-2 \mathrm{CCr}$ based on the results of a previous contract (Reference 25). These coatings were evaluated in a hot corrosion burner rig test at $900^{\circ} \mathrm{C}$, with a $4 \mathrm{ppm}$ salt level in air. After 300 hours of hot corrosion exposure, the depth of hot corrosion penetration was least (19-32 $\mathrm{mm})$ for the $\mathrm{Ni}-\mathrm{Cr}-\mathrm{Cb}$ systems while the $\mathrm{Ni}-\mathrm{Al}-\mathrm{Cr}$ systems showed deeper penetration $(32-50 \mathrm{~mm})$.

The results of a furnace oxidation test are shown in figure 3 . The oxidation resistance of the coated specimens is significantly better than that for oare $1 \mathrm{~N}-792$, with the $3 \mathrm{CD}$ coating being the least oxidation-resistant coating. The data presented in Table III indicate that the $\mathrm{NI}-\mathrm{Al}-\mathrm{Cr}$ and $\mathrm{Ni}-\mathrm{Al}-\mathrm{CD}$ coatings have ductilities significantly better than aluminides. However, the high-cycle fatigue life of IN-792 with these coatings was only equivalent to that of the cormercial RT-22 coating on IN-792.

The $\mathrm{Ni}-13 \mathrm{Al}-1 \mathrm{CO}, \mathrm{Ni}-19 \mathrm{Al}-3 \mathrm{Cb}$ and the $\mathrm{Ni}-12 \mathrm{Al}-2 \mathrm{OCr}$ coatings were applied to the internal surfaces of first-stage Mars Engine turbine blades. Metallgrapnic examination after a 500 hour cyclic endurance test showed that the Ni-19Al-1CO coating provided the best protection. The $\mathrm{Ni}-12 \mathrm{Al}-20 \mathrm{Cr}$ coating was the least protective witn total coating consumption evident in areas of the blade where pack coating volume was insufficient to form a coating of the desired thickness. 
In conclusion, a dry powder pack method for N1-AI-Cb and N1-AI-Cr alloyed aluminide coating systems has been demonstrated through laboratory tests and a ground-based engine test. Compared to the externally applied coating thicknesses, internally applied coating thicknesses were less by 10 to 20 percent because of the restricted pack volume that can be placed in the blade core. The Ni-19AI-1Cb system had superior oxidation and hot corrosion resistance compared to the other 3 systems examired. While the coating ductilit:y was superior to that of simple aluminides, their effects on IN-792 prsperties (tensile, HCF, and stress rupture) were similar to that of aluminide coatings. The report from this contract should be published in the second quarter of 1981, as NASA CR-165337. .

\section{PLASMA SPRAYED COATINGS}

The next two contracts were initiated as the result of NASA Lewis in-house coating efforts in the area of metal overlay and thermal barrier coatings (References 26-47). In the case of the overlay coatings (alloyed-aluminides generally called MCrAlY's', the electron beam-physical vapor deposition (EB-PVO) technique was used to apply MCrAlY overlay coatings on commercial aircraft gas turbine engine blades and vanes. Because EB-PVD is a vaporization process and the vapor pressures of the various elements ( $\mathrm{Ni}, \mathrm{CO}$, $\mathrm{Fe}, \mathrm{Cr}, \mathrm{Al}, \mathrm{Y}, \mathrm{Cb}, \mathrm{Ta}, \mathrm{Si}$, and others) are significantly different, it is difficult to add Si or one of the refractory elements to the MCrAlY metal pool stock and reproducibly obtain the coating composition desired and yet maintain an économic process. 
Recent advances in air- (Reference 48) and low-pressure plasma spray equipment with the help of computerized control have made plasma spraying an attractive alternative to EB-PVD systems. Plasma spray equipment involves significantly lower capital investment, and it is easier to operate and to control the coating composition than with EB-PVD equipment. This becomes more pronounced as the coating compositions become more complex. In addition, the range of available coating compositions is virtually unlimited with the plasma spray process. However, up until recent contractual efforts, EB-PVD coatings have consistently outperformed plasma spray coatings of equivalent composition.

\section{TAILORED PLASMA SPRAY MCRAIY COATINGS FOR GAS TURBINE APPLICATIONS}

The purpose of the investigation, under a contrast with the Commercial Products Division of Pratt and Whitney Aircraft (PWA, East Hartford), was to obtain equivalent or better plasma sprayed coating performance than current electron-beam physical vapor deposited MCrAlY coatings in both the high temperature oxidation and hot corrosion cnvironments found in advanced aircraft gas turbines. Fifteen compositional/process variations of plasma sprayed MCrAlY roatings (NiCoCrAlY and CoCrAIY) were investigated. Table IV shows the processes and coating compositions used for the single crystal alloy 454 (Ni-10Cr-5CO-iW-12Ta-1 5Ti-5AI) in oxidation applications. With the same processes, a CoCrAlY coating (C0-22/29 Cr-10/12.5 Al-0.6 Y) p?us $2.0 \mathrm{Si}$ on B1900 + Hf was investigated for hot corrosion applications.

The microstructures of NiCoCrAir coatings produced by different plasma spray methods !i.e.-air plasma sprayed, one-atmosphere argon chamber plasma 
sprayed (ACS) and low-pressure chamber plasma sprayed (LPCS)) are shown in figure 4. The LPCS NiCoCrAIY's are more dense and have less oxide present in the coating than the ACS and air-plasma sprayed MiCocrair's. The effect of these differences on $1148^{\circ} \mathrm{C}\left(2100^{\circ} \mathrm{F}\right)$ burner rig oxidation life of Mar-MeOO + Hf specimens is shown in figure 5 .

The oxidation results of the best low-pressure chamber plasma spray (LPCS) MCraly + Si coating for each alloy are compared to electron-beam physical vapor deposited (EB-PVD) and LPCS MCrAIY coatings (without Si) in figures 6 and 7. The performance of both MCrAir + Si coatings in these mach 0.3 burner rig tests was superior to those of the EB-PVD and LCPS MCrAlY coatings without Si. In the case of NiCoCrAlY coatings, the silicon addition doubled the life of the coating; the CoCrAiY + Si ccating in the oxidation test $\left(1120^{\circ} \mathrm{C}\right)$ proved to be about fifty percent better than the coatings without Si.

In cyclic burner rig hot corrosion testing at $900^{\circ} \mathrm{C}$ (30 ppm sea salt; equivalent of $1.30 \mathrm{wt}$. percent sulfur in the fuel added via $\mathrm{SO}_{2}$ ), all the MCrAlY coatings with and without additives (Si, Ta, and $\mathrm{HF}$ ) on both alloys provided satisfactory protection beyond 500 hours of exposure.

Superior fracture strain capability was shown by the LPCS MCrAiY coatings over sinilar EB-PVD compositions, figure 8. However, the addition of Si to the LPCS MCrAIY significantly lowered the fracture strain value. The percent fracture strain with $S i$ is less than for EB-PVO coated alloys, but is more than sufficient for the intended application.

In summary, based on laboratory oxidation tests at $1120^{\circ} \mathrm{C}$, the LPCS MCraly-plus-Si coatings on the single crystal alloy 454 and $81900+\mathrm{HF}$ alloys are superior in performance to similar EB-PVD and LPCS MCrAIr coatings without 
Si or with other elemental additions. Hot corrosion test results at $900^{\circ} \mathrm{C}$, showed no significant difference in itfe between costing compositions or processes used. In the $315^{\circ} \mathrm{C}$ ductility test, the LPCS mCrAIY-plus-Si displayed greater ductility than aluminide coatings. Testing of these coated alloys in ground-based test engines will be used to confirm the laboratory results. Tine report (NASA CR-163234) from this contract was published in January 1981.

\section{THERMAL BARRIER COATED TURBIME BLADE STUDY}

Thermal barrier coatings on air-cooled blades can be used to extend the life or increase engine operating efficiency. The actual trade-offs are many and need to be identified with the total engire operation as well as the component involved. The most readily afparent trade-offs are lower component metal operating temperature with extended life, or reduced cooling air with increased engine efficiency while maintaining the same component operating temperature.

The approach taken in this program was to perform a parametric design study to identify the benefits and trade-off factors for a thermal barrier coating on CF6-50 second-stage turbine blades. This blade was selected because it is convection cooled whereas the first-stage blade is film-cooled and thus cannot be readily coated without extensive fixturing. Table $V$ illustrates the data obtained from one such trade-off study where the rupture life and low cycle fatigue (LCF) life factors are compared for a number of cooling-dir flow conditions when the maximum blade temperature is restricted 
to $980^{\circ} \mathrm{C}\left(1800^{\circ} \mathrm{F}\right)$. Using 100 percent cooling-air flow through a bure blade as the baseilne factor of one, $0.025 \mathrm{~cm}$ of coating would increase the rupture life by a factor of 35 and the LCF life by a factor of 1.25 . If there is a local spallation (down to the bond coating) with 100 percent air flow, there still would de a 24-fold increase in rupture life, while the LCF life would fall to 0.7 of the bare-blade baselíne.

Of greatest significarce is the case where cooling air flow is reduced by 50 percent while mainteining the baseline LCF lite.

However, in this fully coated design the bond coat temperature is expected to I imit coating life. Without the trailing edge of the blade coated, somewhat more than 65 percent of the cooling air would be needed to maintain a rupture and LCF life factor of one. This design has the derodynamic advantage of no increase in blade trailing edge thickness. In another study, where a complete redesign of the blide for opt imu:i benefits with a TBC coating was considered (integral design), the cooling-air could be reduced to around 55 percent of the baseline while maintaining the rupture and LCF life of a bare blade and not exceeding $980^{\circ} \mathrm{C}\left(1800^{\circ} \mathrm{F}\right)$ bond coat temperature. The above trade-off studies illustrate the need to examine all of the ramifications involved in applying thermal barrier coatings since their presence (or loss) can change the mechanical and/or physical characteristics of a component far more than any previously used codting system.

Concurrent with the parametric design study, a coating oevelopment effort was performed to evaluate two plasma spray processes and the effects of coating thickness, bond and ceramic coating compositions, and substrate 
composition variables. Specimens were exposed to a series of one-hour furnace cycles from $140^{\circ} \mathrm{C}$ to $1100^{\circ} \mathrm{C}$. The results for each of the variables investigated are illustrated in Figure 9. The study showed that magnesia-stabilized zirconia destabilized while yttria-stabilized materials exhibited no phase changes during the exposure. The ceramic thickness had no significant effect (e 5 percent) on life, while the bond coat deposition process di. The low-pressure/high-velocit." (LP/HV) processed bond coating gave about 25 percent longer life than the conventional air-processed bond coating. Bond coat and substrate composition were also significant variables. An increase in bond coat chromium content from 16 to 22 percent increased life about 20 percent. There was a 17 percent difference in coating life between the two substrate alloys (Rene $80>$ Hastelloy- $X$ ).

The $N i-22 C r-10 A l-1 Y$ bond coating with the $8 Y_{2} O_{3}-2 r O_{2}$ ceramic system deposited by air and LP/HV processes were used to coat specimens for burner rig oxidation and hot corrosion tests, and based on the rig test results, the LP/HV process was used to coat second-stage blades for a CF6-50 engine test. The full-scale land-based CF6-50 engine test showed that thermal barrier coatings developed in this program can operate for at least 625 endurance cycies on the second stage blade. Further testing is in process. The contractor report should be published in the third quarter of 1981, as NASA CR-165351. 


\section{AUTOMATED PLASMA SPRAY PROCESS FEASIBILITY STUDY}

The purpose of this contract with the Equipment Division of TRW was to conduct an automated plasma spray (APS) process feasibility situdy for the application of coating materials to turt ine blades, specifically thermal barrier coatings al this time. The APS equipment developed integrates a multi-axis blade handling fixture, a non-coherent optical instrument for coating thickness measurement, plasma spray equipment operating in the ambient environment, and a microprocessor-based system controller. A schematic of the APS process is shown in Figure 10, and the actual equipment is shown in figure 11. Figure 12 is a close-up showing the plasma gun and optical probe which move up and down along the vertical screw axes. The blade surface is always oriented perpendicular to both the optical probe during measurement and the plasma spray gun during spraying. Through deposition of a series of overlapping strips of spray, any coating contour thickness can be built up on the blade. Coating thickness is measured by manueverirg the blade in front of the optical probe by means of the multi-axis blade handling fixture via the appropriate software program. With feedback from the optical probe measurement, the blade is repositioned if necessary, to complete the desired amount of coating buildup. Further Jetails are given in reference 46.

In Figure 13, a comparison of APS optical probe and metallographic coating tnickness measurements at various locations around a turbine blade airfoil is presented to illustrate the accuracy of the optical probe measurements. Table 
VI shows comparison of the coating unifcrmity and repeatability obtained on manual and APS sprayed blades. Production coated blades will require the uniformity and repeatability of an automated system.

The APS equipment developed is not a production prototype, but was built to prove the feasibility of an automated plasma spray process with feedback control to apply two-layer thermal barrier coatings and as a research and development apparatus to study plasma spray processing. Further improvements in APS durability are required for a production system.

\section{CONCLUDING REMARKS}

Our contractual coatings program efforts follow the directions pointed out by our in-house research and the future technology needs of the aerospace industry. Currently, there is a contract to improve the strain tolerance of thermal barrier coatings. NASA Lewis in-house efforts are continuing to better understand and improve thermal barrier coatings. We are presently studying the metallic coating instability problems associated with oxide dispersion strengthened alloys. In addition, we are addressing methods for overcoming the chemical/mechanical compatability problems anticipated for advanced superalloys and strategic materials conservation alloys. Finally, we are developing an improved coating-life prediction methodology. 


\section{REFEREMCES}

1. S. J. Grisaffe, and J. F. Merutka, "Coatings for Aircraft Gas Turbine Engines and Space Shuttle Heat Shielos, A Review of Lewis Research Center Programs," MASA TM X-68007, 1972.

2. M. Gedwill, and S. Grisaffe, "Ouplex Aluminized Coatings," U.S. Patent $3,869,779,1975$.

3. M. Kaufmar, "Examination of the Influence of Coatirgs on Thin Superalloy Sections, Volume 1, Vescription and Analys is" NASA CR-134791, Vecember 1974.

4. M. Kaufman, "Examination of the Influence of Coatings on Th in Superalloy Sections, Volume 11, lietailed Procecures and Vata," NASA CR-13479\%, December 1974.

5. M. Kaufman, "Examination of the Influence of Coatings on Th in Superalloy Sections," MASA CR-121115, August 197\%.

6. M. A. Gedwill, and S. J. Grisaffe, "Oxidation Resistant Claddings for Supercilloys," NASA TM X-67925, 1971.

7. H. C. Fiedler, and R. J. Sieraski, "Aluminide Coatings for Nickel-Base Alloys," General Electric Co., Schenectady, N.Y., SRU-7ZZ-0Z8; NASA CR-120871, 1971 .

8. S. 6. Young, and G. R. Zellars, "Feasibility Study of Tungsten as a Uiffusion Barrier Between Nickel-Chromium-Aluminum and Gamma 'Gamma Prime - Velta Eutectic Alloys," NASA TP-1131, 1978.

G. M. A. Gedwill, "Cyclic Oxication of Coated Oxide Uispersicn Strengthened (OCIS) Alloys in High Velocity Gas Streams at $1100^{\circ} \mathrm{C}$, "NASA TM-78877, 1978. 
10. T. E. Strangman, E. J. Felten, and N. E. Ulion, "High Temperature Oxidation Resistant Coatings for the Directionally Solidified Mi-Mb-Cr-Al Eutectic Superalloy," Am. Ceram. Soc. Bull., 56 [8] 700-705 (1977).

11. T. E. Strangman, E. J. Felten, and R. S. Benden, "Refinement of Promis ing Coating Compositions for Directionally Cost Eutectics," Pratt and Whitney Aircraft, East Hartford, Conn., PWA-5441; NASA CR-135103, October 1976.

12. E. J. Felten, T. E. Strangman, and N. E. Ul ion, "Coatings for Virectional Eutectics, Pratt and Whitney Aircraft, East Hartford, Conn., PWA-5091; NASA CR-134735, OCtober 1974.

13. 0. A. Spera, and S. J. Grisaffe, "Life Prediction of Turb ine Components: On-Going Studies at the NASA Lewis Rasearch Center," MASA TM $x-2664,1973$.

14. M. R. Jackson, J. R. Rairden, and L. V. Hampton, "Codtings for Virectional Eutectics," General Electric Co., Schenectady, N.Y., SRU-74-047; NASA CR-134665, Jinuary 1974.

15. S. R. Levine, and J. P. Merutka, "Performance of Coated Columbium and Tantalum Alloys in Plasma Arc Reentry Simulation Tests, " NASA TN 0-7617, 1974.

¿.. J. [i. Cu 1p, "Outer Sk in Protection of Columbium Thermal Protection System (TFS) Pane Is, "McDonnell-Douglas Astronautics Co., St. Louis, Mo., MLC-EOg13; NASA CR-134535, September 1973.

17. B. Fitzerald, "Fused Slurry Silicide Coatings for Columbium Alloy Reentry Heat Shields, Volume 1 - Evaluation Analysis," McConnell-Douglas Astronautics Co., St. Lou is, Mo., MOC-z̈0784-Vol-1; MASA CR-121216, August 1973. 
18. B. Fitzgerald, "Fused Slurry Silicide Cootings for Columbium Alloy Reentry Heat Shields, Volume 2 - Experimental and Coating Process Vetails," Mclionnell-Uouglas Astronautics Co., St. Louis, Mo., MOC-E0784-Vol-?; NASA CR-134483, August 1973.

19. C. M. Packer, and R. A. Perk ins, "Modified Fused Silicide Coatings for Tantalum (Ta-10W) Reentry Heat Shields," Lockheed Missiles and Space Co., Palo Alto, Cal., U3168¿4; MASA CR-120877, April 1973.

20. R. V. Warrock, and A. R. Stetson, "Levelopment of fused Silicide Coatings for Tantalum Re-Entry Heat Shields," Solar Vivision of International Harvester, San Diego, Cal., RCR-1685-7; NASA CR-1210ZZ, September 1373.

21. A. Pearson, "Feasibility and Process Scale-up Low Cost Alumina Fibers for Advanced Re-Usable Surface Insulation (RS1)," NASA CR-134884, October 1975.

"Z. E. L. Strauss, "Evaluation of Low Cost/High Temperature Insulation," Mart in Marietta Aerospace, lenver, Colo., MCR-75-262; NASA CR-134902, November 1975.

23. W. G. Long, "Llevelopment of Fine-Uiameter Mullite Fiber," Babcock and Wilcox Co., Augusta, Ga., LRC-5467; NASA CR-13461ź, February 1974.

24. T. 1. Ormiston, "Improved Coating for Silica Fiber Based Ceramic Reusable Surface Insulation (CRSI)," NASA (R-134653, April 1974.

25. L. Hsu, W. G. Stevens, and A. R. Stetson, "Internally Coated Air-Cooled Gas Turhine Blading," Solar Turbines International, San Uiego, Cal., SR79-R-4655-15; NASA CR-159574, Apri1 1979.

26. S. G. Young, and U. L. Leadmore, "An Experimental, Low-Cost, Silicon Slurry/Aluminide High-Temperature Coating for Superalloys, "NASA TM-79178, 1970. 
27. S. R. Levine, "Coatings for High Temperature Applications," Inst. Metall. [Course Vol.] Series 3 [10] (Surface Treatments for Protection) 157-169 (1978).

28. 0. L. Deodmore. "High-Velocity Oxidation Performance of Metal-ChromiumAluminum (MCrAl), Sermet, and Modified Aluminide Coatings on $1 \mathrm{~N}-100$ and Type VIA Alloys at $1093^{\circ} \mathrm{C}$, " MASA TN 0-7530, 1974.

29. M. A. Gedwill, "Improved Bond Costings for Use with Thermal Barrier Coot," DOE/MASA/2593-18, MASA TM-81567, 1580.

30. P. E. Hodge, R. A. Miller, and M. A. Gedwill, "Evaluation of Hot Corrosion Behavior of Thermal Barrier Coatings," DOE/MASA/2593-16, MASA $T M-81520,1980$.

31. G. Mctonald and R. C. Hendricks, "Effect of Thermal Cycling on 2R02-r203 Therms 1 Barrier Codtings," NASA TM-81480, 1980.

32. S. Stecura, "Performance of Two-Layer Thermal Barrier Systems on Directionally Solidified NI-Al-Mo and Comparative Effects of Alloy Thermal Expansion on System Life," NASA TM-81604, 1980.

33. 1. Zaplatynsky, "Comparative Evaluation of Insulating Properties of Plasma Sprayed Ceramic Coatings," Ceramic Engineering and Science Proceeding̣, 1 (7-8(B)) 608-623 (1980).

i4. R. A. Miller, "Analysis of the Response of a Thermal Barrier Coating to Sccium and Vanacium unped Combustion Gases," COE/NASA/2593-79/7, NASA IM-79\%05, 1979.

35. S. Stecura, "Effects of Compositional Changes on the Performance of a Thermal Barrier Coating System," NASA IM-78976, 1978.

36. S. Stecura, "Effects of rttrium, Aluminum, and Chromium Concentrations in Bond Coatings on the Performance of 2 irconio-rttria Thermal Barriers, NASA TM-79206, 1979. 
37. P. E. Hodge, S. Stecurd, M. A. Gedwill, 1. Zaplatynsky, and S. R. Levine, "Thermal Barrier Coat ings: Burner Rig Hot Corrosion Test Results," DOF. INASA/Z593-78/3, NASA TM-79005, 1978.

38. S. R. Levine, "Adhes ive/Cohesive Strength of $\mathrm{ZrO}_{2} \cdot 12$ w/o $\mathrm{Y}_{2} \mathrm{O}_{3} /$ NiCraly Thermal Barrier Coating," NASA TM-7379\%, 1978.

39. 1. Zaplatynsky, "Reactions of Yttria Stabilized Zirconio with Oxides and Sulfates of Various Elements," LOE/NASA/2593-78/1, NASA TM-7894\%, 1978.

40. S. Stecura, and C. H. Liebert, "Thermal Barrier Coating System," U.S. Patent No. 4055705, October 25, 1977.

41. S. Stecura, "Two-Liyer Thermal Barrier Coating for High Temperature Components," Am. Ceram. Soc. Bull., 56 (12) 1082-1085, 1089 (1977).

4\%. 1. Zaplatynsky, "Oxidation Behavior of NiCrAlY-MgO and NiCrAlYZirconate-Type Cermets," NASA TM X-3466, 1976.

43. C. H. Liebert, R. E. Jacobs, S. Stecura, and C. R. Morse, "Uurability of Zirconia Thermal-Barrier Ceramic Coatings on Air-Cooled Turbine Blades in Cyclic Jet Engine Operation, NASA TM X-3410, 1976.

44. S. Stecurd, "Two Layered Thermal Barrier Ccating for Turbine Airfoils Cyclic Furance and Burner Rig Test Results, " NASA TM X-3425, 1976.

45. C. H. Lifbert, and S. Stecura, "Ceramic Thermal Protective Coating Withstands Hostile Environment of Rotating Turbine Blades," MASA Tech Brief B75-10ะSO, 1975.

46. C. W. Fetheroff, T. Clerkacs, and 1. M. Matay, "Automated Plasma Spray (APS) Process Feasibility Study: Plasma Spray Process Vevelopment and Evaluation; TRW, Inc., Cleveland, Oh., TRH-ER-8019-1; NASA Cr-159579, May 1979. 
TABLF I. - LASER SCREENIIG IE STS OF TITANUUM FIRE PREVENTION COATINGS

\begin{tabular}{|c|c|c|c|c|c|}
\hline \multirow{2}{*}{\multicolumn{2}{|c|}{$\begin{array}{l}\text { NOMBNaL ENGINE CONOITONS } \\
350^{\circ} \mathrm{ClQ} .70 \mathrm{MPa} / 24 \mathrm{~m} / \mathrm{s}\end{array}$}} & \multicolumn{4}{|c|}{ ACCELERATED TESTS } \\
\hline & & \multicolumn{2}{|c|}{$45^{\circ} \mathrm{Cl} .76 \mathrm{MPa} / 2 \mathrm{~m} \mathrm{~m} / \mathrm{s}$} & \multicolumn{2}{|c|}{$455^{\circ} \mathrm{C} / \mathrm{Q} .96 \mathrm{MP} / 244 \mathrm{~m} / \mathrm{s}$} \\
\hline COATING & SBURN & COATING & s BURN & COATING & S BURN \\
\hline 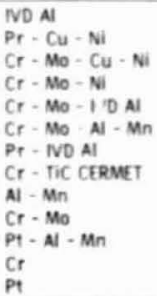 & $\begin{array}{r}0 \\
0 \\
0 \\
0 \\
13 \\
0 \\
0 \\
0 \\
0 \\
0 \\
56 \\
67 \\
100\end{array}$ & 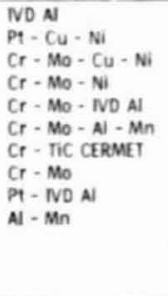 & $\begin{array}{l}1 \\
0 \\
0 \\
0 \\
0 \\
0 \\
1 \\
37 \\
37 \\
55\end{array}$ & $\begin{array}{l}\mathrm{ND} A \mathrm{Al} \\
\mathrm{PI}-\mathrm{CL}-\mathrm{Ni} \\
\mathrm{Cr}-\mathrm{MO}_{0}-\mathrm{Cu}-\mathrm{Ni} \\
\mathrm{Cr}-\mathrm{Mo}_{0}-\mathrm{Ni} \\
\mathrm{Cr}-\mathrm{Mo}_{0}-\mathrm{ND} \text { Al } \\
\mathrm{Cr}-\mathrm{MO}_{0}-\mathrm{Al}-\mathrm{Mn} \\
\mathrm{Cr}-\mathrm{TiC} \text { CERMET }\end{array}$ & $\begin{array}{l}47.5 \\
47.0 \\
446 \\
38.8 \\
60.0 \\
647 \\
100.0\end{array}$ \\
\hline
\end{tabular}

TABLE IIL - INTERNAL COATING STRAIN TOERANCE TEST RE SULTS

\begin{tabular}{|c|c|c|c|c|}
\hline \multirow[t]{2}{*}{ COATING } & \multicolumn{2}{|c|}{ TEMPERATURE } & \multicolumn{2}{|c|}{ STRAIN (\$) } \\
\hline & ${ }^{10} \mathrm{Cl}$ & $\left({ }^{\circ} \mathrm{F}\right)$ & $\begin{array}{c}\text { NO } \\
\text { CRACKS } \\
\text { OB SERVED }\end{array}$ & $\begin{array}{l}\text { CRACKS } \\
\text { OB SERVED }\end{array}$ \\
\hline $\mathrm{Ni}-19 \mathrm{Al}-1 \mathrm{CD}$ & 27 & 80 & 1.0 & 1.7 \\
\hline $\mathrm{Ni}-19 \mathrm{Al}-1 \mathrm{CD}$ & 87 & 800 & 2.0 & 2.7 \\
\hline $\mathrm{Ni}-19 \mathrm{Al}-1 \mathrm{CD}$ & 538 & 1000 & 2.2 & 2.8 \\
\hline $\mathrm{Ni}-19 \mathrm{Al}-1 \mathrm{CD}$ & 538 & 1000 & 1.2 & 1.7 \\
\hline $\mathrm{Ni}-19 \mathrm{Al}-1 \mathrm{CO}$ & 649 & 1200 & 2.4 & 27 \\
\hline $\mathrm{Ni}-19 \mathrm{Al}-3 \mathrm{CD}$ & 07 & 800 & 2.6 & 3.1 \\
\hline $\mathrm{Ni}-19 \mathrm{Al}-3 \mathrm{CD}$ & 58 & 1000 & 1.2 & 1.7 \\
\hline $\mathrm{Ni}-17 \mathrm{Al}-20 \mathrm{Cr}$ & 07 & 800 & 2.5 & 3.0 \\
\hline $\mathrm{Ni}-17 \mathrm{Al}-20 \mathrm{Cr}$ & $5 \times$ & 1000 & 14 & L.8 \\
\hline $\mathrm{Ni}-12 \mathrm{Al}-20 \mathrm{Cr}$ & 427 & 800 & 2.5 & 2.9 \\
\hline $\mathrm{Ni}-12 \mathrm{Ai}-20 \mathrm{Cr}$ & $5 \%$ & 1000 & 1.5 & 1.9 \\
\hline
\end{tabular}

NOT. TWO STRAIN VALUES ARE LISTED, ONE FOR THE LAST STRAIN INCREMENT BEFORE CRACKING WAS DETECTED AND THE OTHER FOR WER CRACKS WERE ACTUALIY FOUND. TYPICAL ALUMINIDE COATING DUCTUITY AT $43^{\circ} \mathrm{C}$ IS 0.45
TABLE II. - SUMMARY OF TEST RESUL IS FOR COATED Ti-8AI-1MO-1V ALLOY PROPERTIES

\begin{tabular}{|c|c|c|}
\hline PROPERTY EVALUATED & $\mathrm{Pt} / \mathrm{Cu} / \mathrm{Ni}$ & NDD Al \\
\hline COMBUSTION RESISTANCE & • & $+*$ \\
\hline HCF & 0 & 0 \\
\hline TENSILE & 0 & 0 \\
\hline CREEP RUP TURE & 0 & 0 \\
\hline HOT SALI S.C. RESISTANCE & 0 & 0 \\
\hline STRESS RUPTURE & + & 0 \\
\hline EROSION RESIF:ANCE & + & + \\
\hline ADHES $r$. & 6000 & 6000 \\
\hline STATIC OXIOATION RESISTANCE & - & - \\
\hline DIFFUSION & 0 & 0 \\
\hline THERMAL. SHOCK RESISTANCE & 0 & 0 \\
\hline STRESS ANAL YSIS & 0 & 0 \\
\hline
\end{tabular}

WHERE: 0 - NO SIGNIFICANT INFLUENCE DUE TO COATING - coating had degrading effect on baseline * coAting appeared to provide improvenent UVER BASELINE

TABLE IV. - CANDIDATE CDATINGS AND PROCESSES EVALUATED ON THE SINGLE CRYSTAL NLL:: 454

\section{Processes}

- Electron beam vapor deposition (baselinel

- Low pressure chamber plasma spray

- Atmospheric argon plasma spray

\section{Coatings}

- NiCoCrAIY + HF (0.8 w/o Hf

- NiCoCraly + Ta $(8.0$ w/o Ta)

- NiCoCralr + Si (1.2 1.6. 2.1 w/o Si

- NiCocralr + Si + Ta (1.6Si-4.0Ta, 1.6Si-8.0Ta) 
TABLE V. - POTENTIAL EFFECT OF A THERMAL BARRIER COATING ON THE LIFE OF CF6-50 ZHPT BLADE

\begin{tabular}{|c|c|c|c|c|}
\hline CONFIGURATION & $\begin{array}{l}\text { COOUING } \\
\text { AlR } \text { * }\end{array}$ & $\begin{array}{c}\text { CERAMIC } \\
\text { THICKNESS. } \\
\mathrm{Cm} \\
\end{array}$ & $\begin{array}{c}\text { RUPTURE } \\
\text { LIFE } \\
\text { FACTOR } \\
\end{array}$ & $\begin{array}{c}\text { LCF } \\
\text { LIFE } \\
\text { FACTOP } \\
\end{array}$ \\
\hline BARE BLADE & $100 \%$ & 0 & 1.0 & 1.0 \\
\hline "FuLLY CoATED & $100 s$ & acos & 35.0 & 1.25 \\
\hline "FuLir coated & $50 s$ & a ORS & 9.7 & 1.0 \\
\hline FULYY COATED EXCEPT T.E. & $65 \%$ & Q. 037 & 1.0 & Q.9 \\
\hline "WORST LOCAL SPALLATION & $100 \%$ & a.cos & 240 & Q.7 \\
\hline
\end{tabular}

"982 $\mathrm{C}$ BOND COAT LIMIT EXCEEDED AT TRAIL ING EDGE
TABLE VI. COMPARISON OF COATING UPIFORMITY AND REPRODUCIBIUITY FROM MANUALIY AND AUTOMATED PLAS' ¿A SPARAYED (APS) TURBINE BLADES

$\frac{\text { COATING }}{\text { UNIFORMITY }} \underset{\frac{\text { MANUAL }}{46 \mathrm{~m}(3 \mathrm{mils})}}{\frac{\text { APS }}{4.5 \mathrm{mils}}}$

REPEATABILITY (10 BLADE AVERAGE)

NICTAIY BOND COATING $\pm 112 \mathrm{um}(4.4 \mathrm{mils}) \quad \pm 68.1 \mathrm{um}(2.1 \mathrm{mils}$ TOTAL COATING $\quad \pm 190 \mathrm{um}(7.5$ mils $) \quad \pm 98.3 \mathrm{~mm}(2.9 \mathrm{mils})$

LIFE FACTOR - $\left\{\frac{\text { CALCULATED LIFE COATED }}{\text { CALCULATED LIFE UNCO'ITOD }}\right\}$

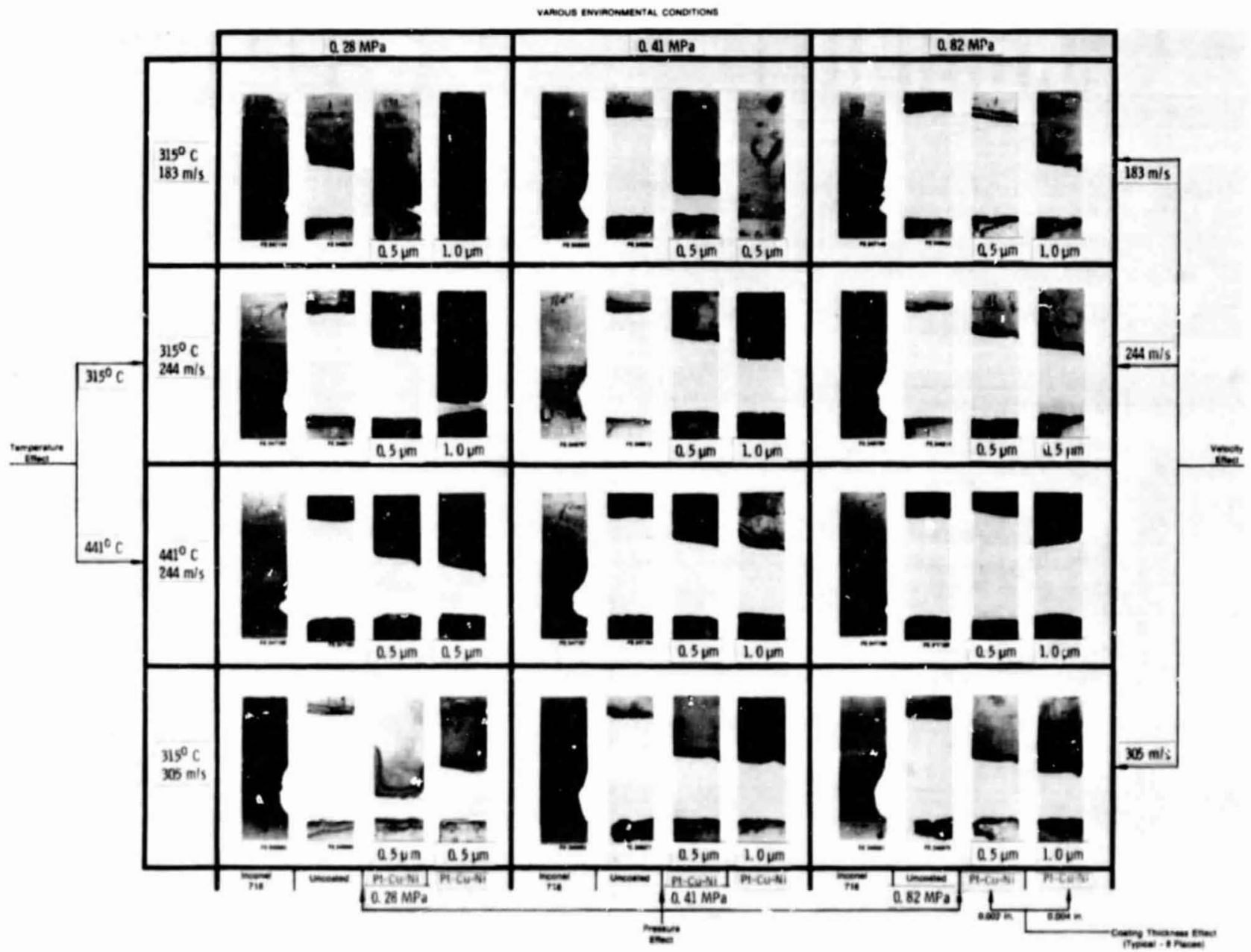

Figure 1. - Pt-Cu-Ni coated specimens after combustion screening tests. 


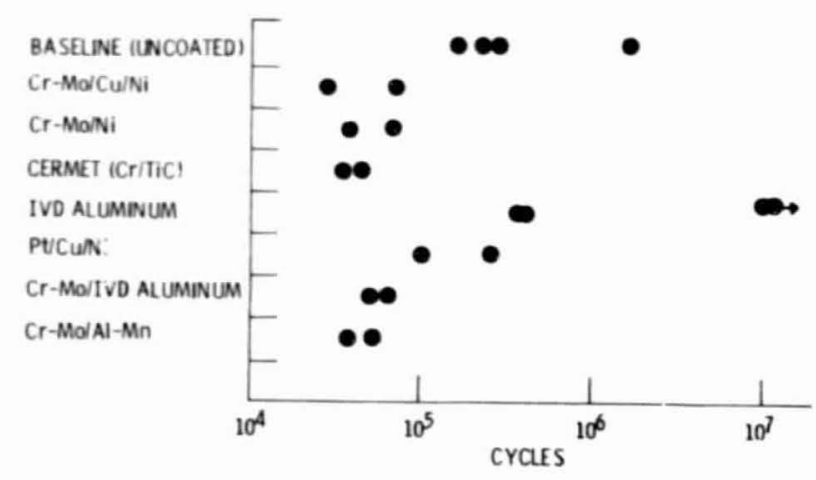

Figure 2 - Reverse bending fatigue results of coated Ii $8 \mathrm{Al}-1 \mathrm{MO}-1 \mathrm{~V}$. IR -1 , alternating stress $-+0.38 \mathrm{GP}$ temperature $\cdot 20^{\circ} \mathrm{C} .1$

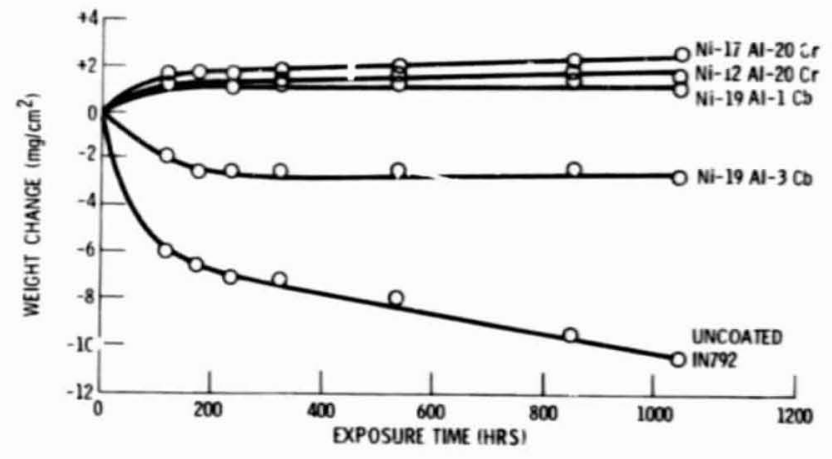

Figure 3. - Furnace axidation weight change rate for potential internal coating $50^{\circ} \mathrm{C}\left(19 x^{\circ} \mathrm{Fl}\right.$

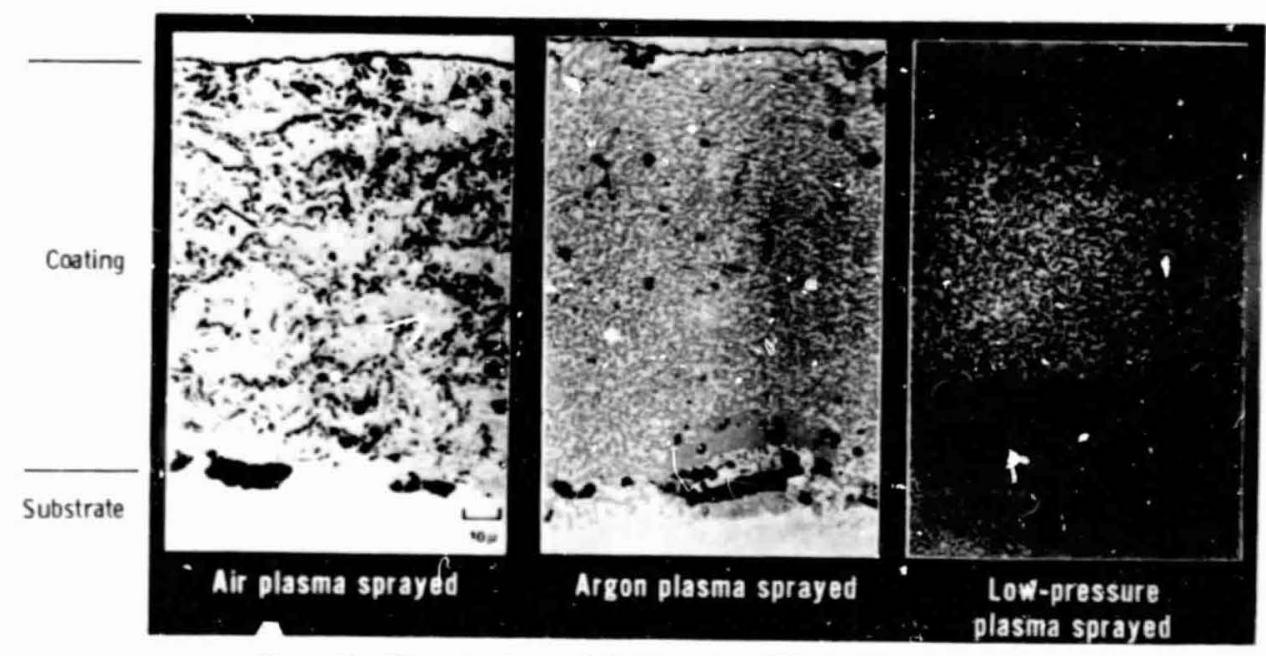

Figure 4. - Microstructures of plasma sprayed NiCoC:-AlY coatings. 


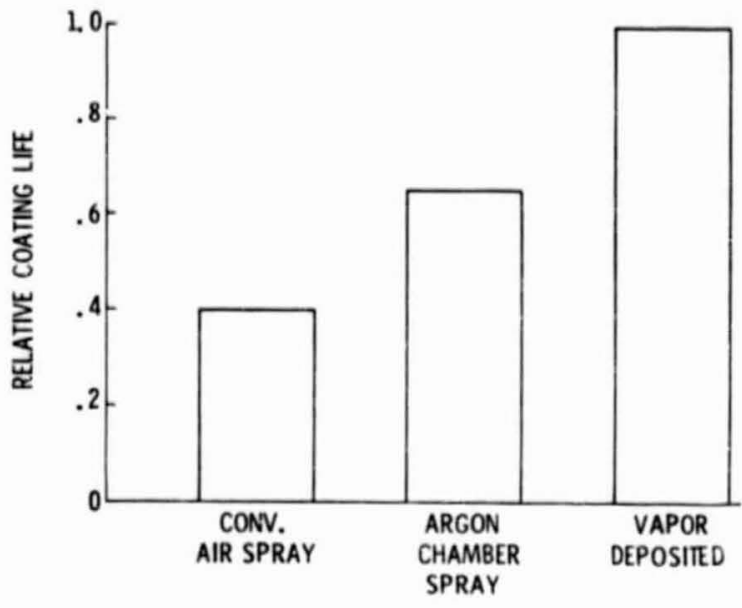

Fi. re 5. - Previous experience. $1148^{\circ} \mathrm{C}$ Mach 0.3 burner i $g$ oxidation life of NiCOCrAlY coatings on Mar-M $200+\mathrm{Hf}$.

\author{
BASED ON FAILED SAMPLES \\ EXTRAPOLATED FROM \\ UNFAILED SPECIMENS \\ EB-PYD - ELECTRON BEAM PHYSICAL \\ VAPOR DEPOSITION \\ LPCS - LOW PRESSURE CHAMBER \\ PLASMA SPRAY
}

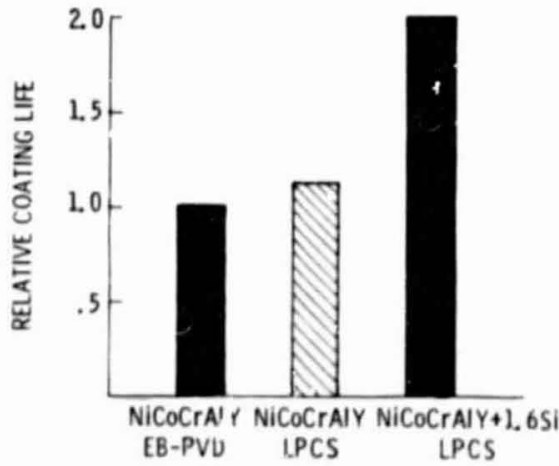

Figure 6. $-1120^{\circ} \mathrm{C}\left(2050^{\circ} \mathrm{F}\right.$ B Burner rig life of NiCoCrAlY based coatings on a single crystal alloy 454 . 


\section{BASED ON FAILED SAMPLES \\ 510 EXTRAPQLATED FROM \\ UNFAILED SPECIMENS}

EB-PVD - ELECTRON BEAM PHYSICAL

VAPOR DEPOSTION

LPCS - LOW PRESSURE CHAMBER

PLASMA SPRAY

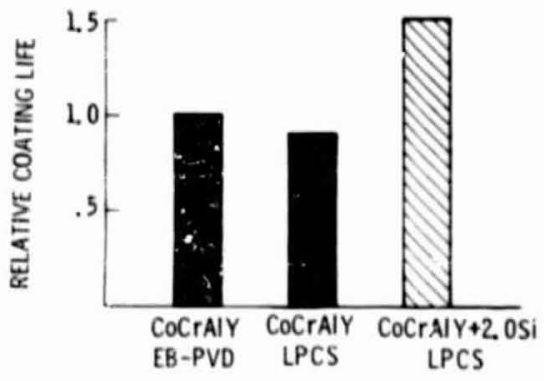

Figura 7. $-1120^{\circ} \mathrm{C}\left(2050^{\circ} \mathrm{F}\right)$ Burner rig life of CoCrAlY based coatings on $\mathrm{B} 1900+\mathrm{Hf}$ alloy.
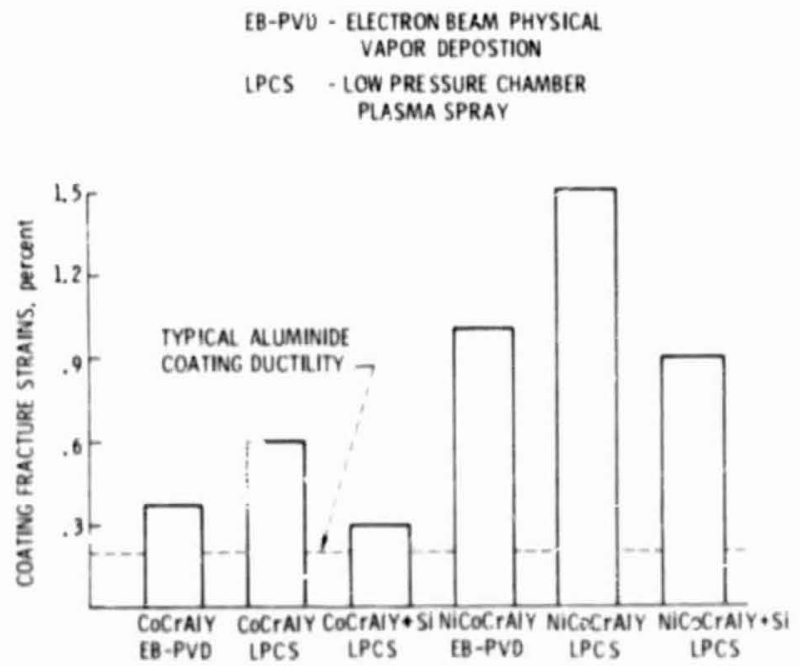

Figure 8. $-315^{\circ} \mathrm{C}\left(600^{\circ} \mathrm{f}\right)$ crating tensile ductility test results on cosied $B 1000+$ Hf alloy 

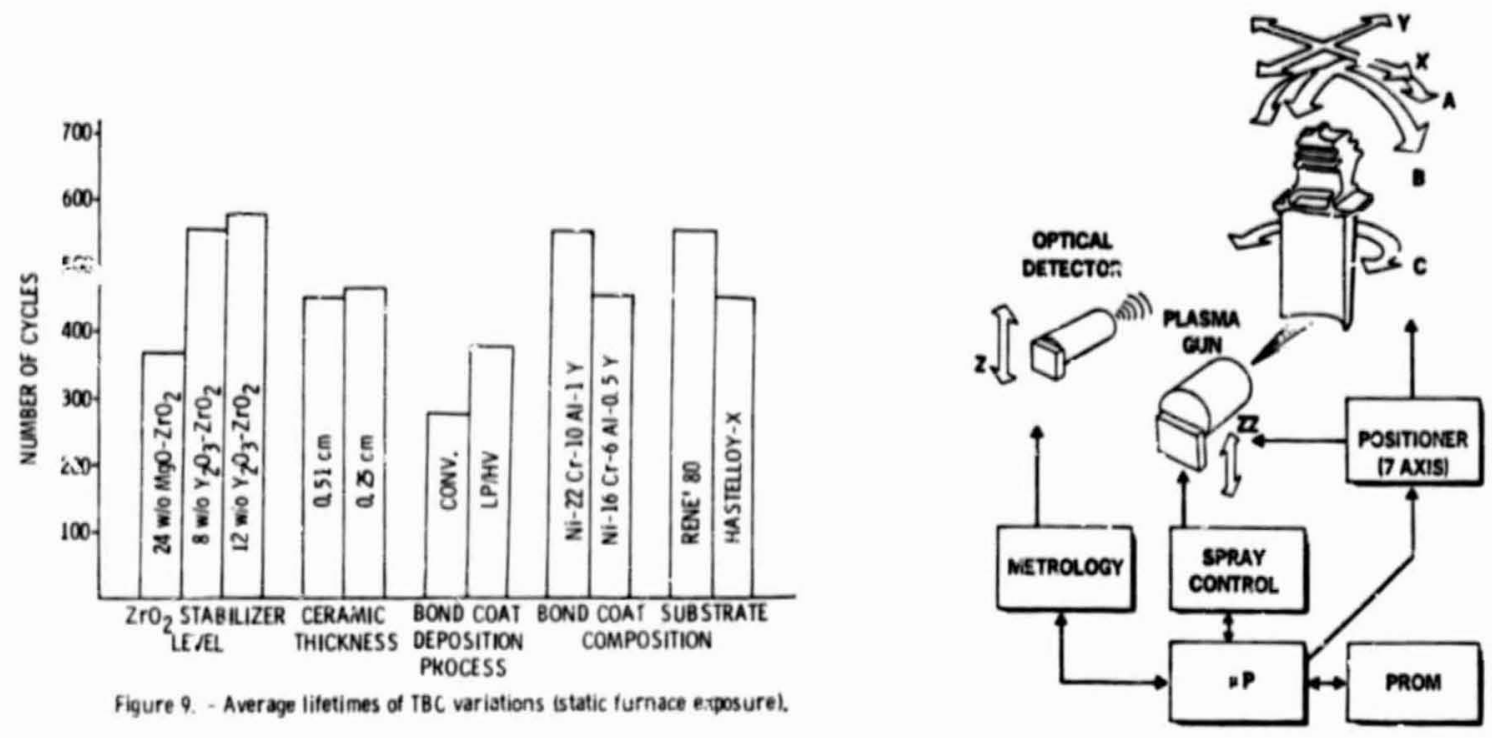

Figure 10. Automated plasma spray process.

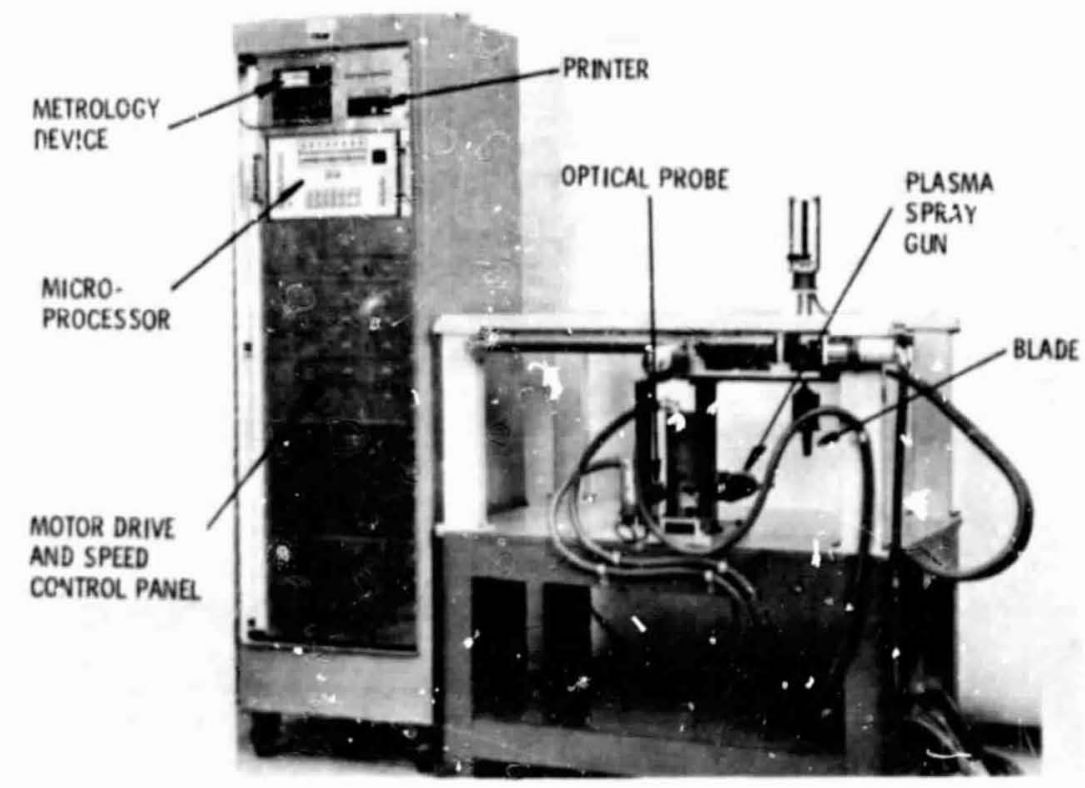

Figure 11. - Automated plasma spray system. 


\section{OR:GINAL PAGE IS
OF POOR QUALTY}

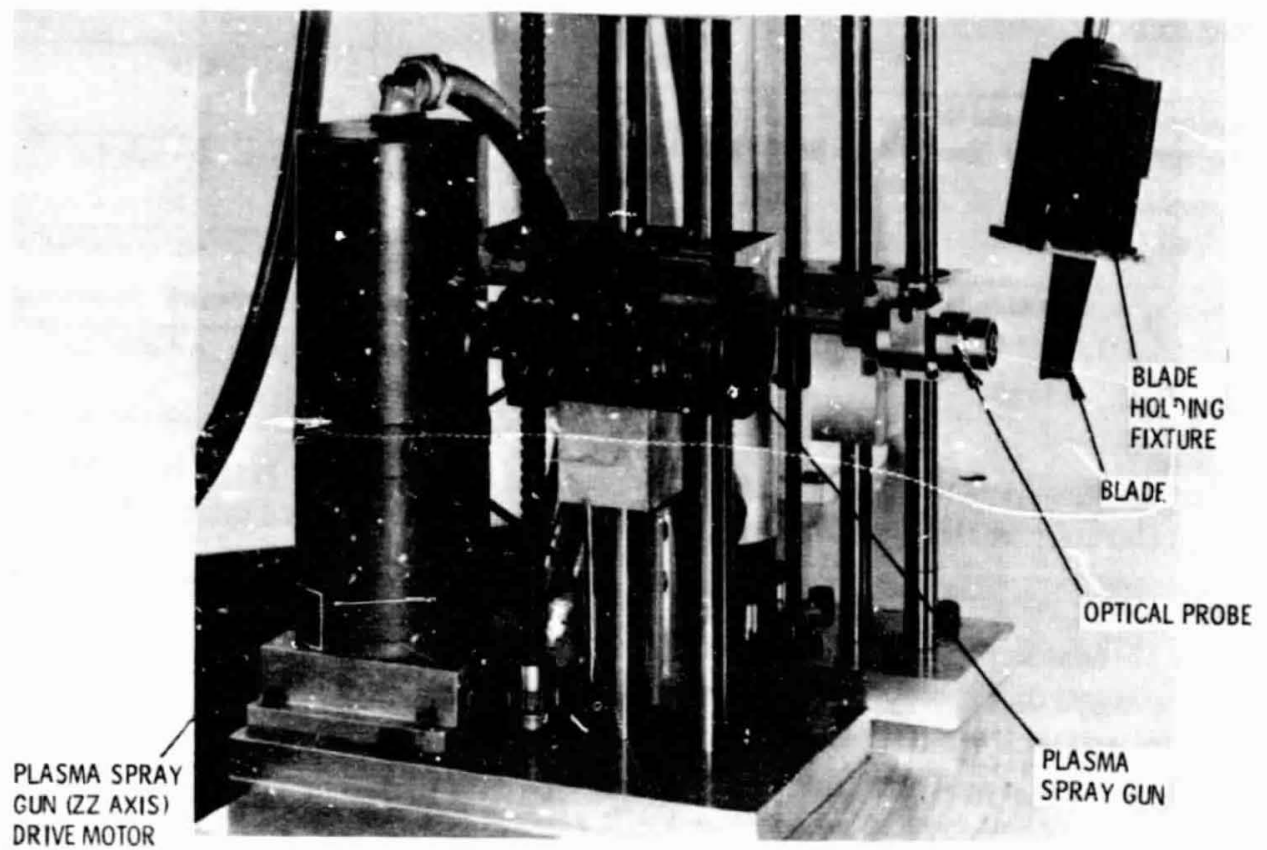

Figure 12. - Closeup of the automated plasma spray system during gage point measurement.

X50 MICROGRAPH MEASUREMENTS

$\triangle$ OPTICAL PROBE. DATA

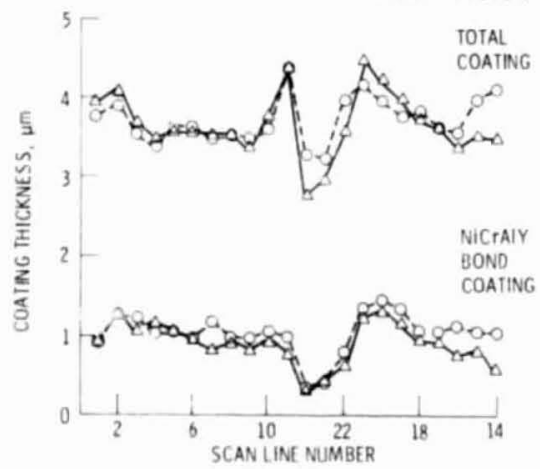

BLADE CONVEX SIDF BLADE CONCAVE SIDE

Figure 13, - Comparison of corting inickness measurements by APS

optica! prohe and metailography. 